\title{
GIS based modeling using Analytic Hierarchy Process (AHP) for optimization of landfill site selection of Rohtak city, Haryana (India)
}

\section{Meena Deswal}

Environmental Sciences Department, Maharshi Dayanand University Rohtak (Haryana), India J.S. Laura

Environmental Sciences Department, Maharshi Dayanand University Rohtak (Haryana), India

${ }^{\star}$ Corresponding author. E-mail:meenadeswal02@gmail.com

\section{Article Info}

DOI:10.31018/jans.v10i2.1753

Received: February 1, 2018

Revised: March 20, 2018

Accepted: April 20, 2018

\section{How to Cite}

Deswal, M. and Laura, J.S. (2018). GIS based modeling using Analytic Hierarchy Process (AHP) for optimization of landfill site selection of Rohtak city, Haryana (India). Journal of Applied and Natural Science, 10(2): $633-642$ ty modeling and analytical hierarchy process (AHP). Site suitability modeling was Rules and criteria's Health and Environmental Engineering Organisation (CPHEEO) were implemented through Boolean model. The combination of the results of the two models generated a map with several suitable sites. Further selection was done on basis of the size requirement of the site, to handle Municipal solid waste (MSW) for next ten years. Two sites having the maximum suitability and also fulfilling the size requirement were shortlisted. Final selection from the two sites was done by a field survey of the sites. Finally the site $B$ was selected on the basis of field survey which revealed it being better on account of certain factors discussed and social acceptability.

Keywords: Analytical hierarchy process, Boolean model, GIS, Index overlay model Landfill, MSW

\section{INTRODUCTION}

Increasing population and urbanization has resulted in municipal solid waste management problems (Sumathi et al., 2008). Not only increased quantity but the composition of waste has also changed. It is estimated that about 62 million tonnes of waste is generated in India among which 5.6 million is plastic, 0.17 million is biomedical, 7.90 million is hazardous waste and 1.5 million is e-waste. 43 million tonne per annum (TPA) is collected among which only 11.9 million is treated and 31 million is dumped in landfill sites. More than $70 \%$ of collected waste is dumped at landfills and most of them are full. It is estimated that waste generation will be 436 million tons by the 2050. In India, Delhi generates maximum quantity of waste (3.3 TAP) which is followed by Mumbai (2.7 TAP), Chennai (1.6 TAP), Hyderabad (1.4 TAP) and Kolkata (1.1 TAP). At present there are three landfill sites in Delhi and 3 in Mumbai which have an area of 66.4 hectare and 31.4 hectares, whereas two dumpsites in Chennai with 465.5 hectare area cover, and in Hyderabad and Kolkata 1 site each is present with an area covering124.5 hectare and 24.7 hectarere respectively. If cities continue to dump the waste at present rate without treatment, it will need 1240hectares of land/ year with a projected generation of 165 million tonne of waste by 2031. The requirement of setting up of the land fill for 20 years of 10 meters height will require 66,000 hectares of land (MoEFCC, 2016). Whatever methodology or technology is used for solid waste management, some amount of waste always remains as a residue which has be disposed off at a safe location. A properly located landfill is of utmost important as its improper site selection may result in environmental degradation and a nuisance to the stakeholders due to leachate percolation, foul order, and pathogens etc, associated with the waste 
Deswal M. and Laura J.S. / J. Appl. \& Nat. Sci. 10 (2): 633 - 642 (2018)

(Sadek et al., 2006; Yıldırım, 2012; Alanbari et al., 2014).The identification of a suitable site for a sanitary landfill is a process requiring a detailed evaluation of certain factors. The factors are more or less the same all over the world but the relative importance of these factors differs according to the geographical location and local socio-economic conditions (Dipanjan et al., 1997; CPCB, 1999).In India these factors are given by Central Public Health and Environmental Engineering Organization (CPHEEO) (Swachh Bharat Mission,2016). Some of the factors having quantities can be compared, but certain factors are not quantitative in nature and cannot be compared mathematically andalso, all factors are not equally important, some are more important, so a weight is given to each factor relative to each other. However, the quantitative values of weightage to each factor have to be decided. Analytic hierarchy process (AHP) is used to compares each factor with all other factors and a comparative weight is obtained for each factor (Rahmat et al. 2017; Nascimento et al. 2017). GIS has evolved as an important technique for land use suitability analysis. GIS has the capability to recognize, correlate and analyze the spatial relationship between mapped data, link disparate sources of information and perform sophisticated analysis (Malczewski, 2004). The objective of this work is to select a suitable land site for the establishment of a landfill for Rohtak city, taking into account suitable factors and regulations/ recommendations given in CPCB and CPHEEO.

\section{MATERIALS AND METHODS}

Study area: Rohtak city situated at a mean sea level of 220 meters (Fig.1). It is located in Haryana state of India. Due to increase in population and urbanisation over the years, the municipal limits have expanded, in 2007 the area coverage of the city was $30.96 \mathrm{Km}^{2}$, and the city limit was extended in 2010 increasing the area coverage to $104.10 \mathrm{Km}^{2}$. In 2012 the municipal corporation expanded the city limits to include nine surround-

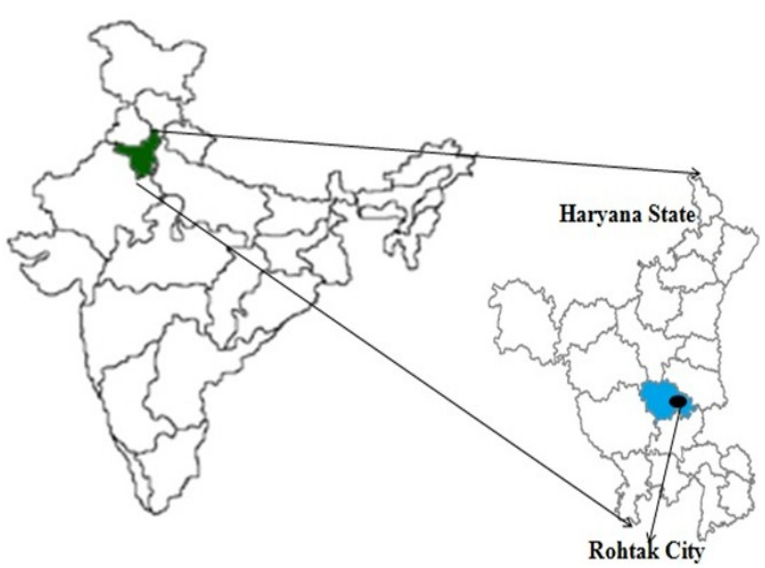

Fig.1. Location map of study area.

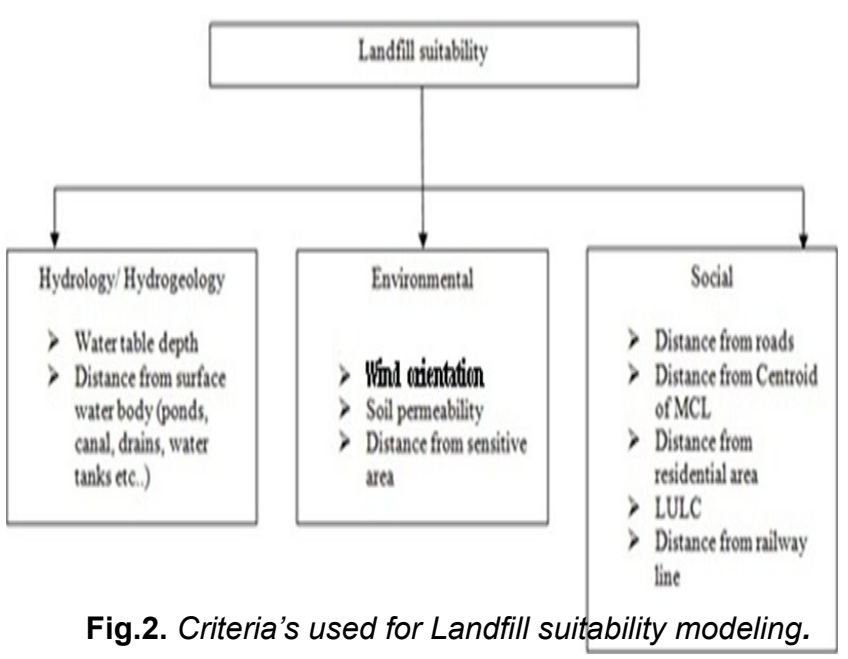

ing villages resulting in the city area coverage increasing to $139.4 \mathrm{Km}^{2}$, and with the population increasing to 3.7 lac (Source-Municipal Corporation Rohtak). In 2012 surrounding nine villages were added after which population of Rohtak city becomes 470328 (Source-Municipal Corporation Rohtak).

Methodology: Various data pertaining to required criteria were collected from National Remote Sensing Center- Indian Space Research Organisation (NRSC-ISRO), Survey of India (Sol), and Municipal Corporation Rohtak (MCR). Toposheet number of H43W9 of scale 1:50,000. The Projection system was Universal Transverse Mercator (UTM) and Datum was World Geodetic System (WGS84). It was used for as a base map for Georeferencing and municipal limits.It was procured from Haryana Geospatial data center, Sol. Cartosat 1 imagery was procured from NRSCISRO, Hyderabad and date of acquisition of data was 28 March 2013. Cartosat 1 imagery was used for the generation of various required layers (surface water bodies, roads, canal, drain, railway line, urban centers and villages). Master plan of Rohtak City for the year 2031 was collected from the Rohtak Town Planning office. Master planmap was used for the generation of expansion limits up to 2031, and future plans of Urban Local bodies for Land Use and Land Cover (LULC). Data pertaining to the following parameters- Wind direction, soil permeability and ground water table were obtained through grid sampling.

Methods: Recognition of weighing up criteria required for suitable site selection for landfill in Rohtak City were identified and evaluated. These criteria had been selected as per the norms given in Central Public Health and Environmental Engineering organisation (CPHEEO), 2016 and Solid Waste Management (SWM) Rules, 2016 (India). The evaluation factors used were grouped into three types of broad categories, hydrological/ hydro-geological (water depth and distance from surface water body), environmental (wind orienta- 
tion, soil permeability, and distance from sensitive area) and social criteria (Distance from roads, centroid of Municipal Corporation limits, residential area, railway lines, roads, canals, and Land Use Land Cover) as shown in Fig.2( Şener et al., 2010; Vasiljevic et al., 2012; Yal and Akgün, 2013; Shahabi et al., 2014; Baba et al., 2015; Yıldırım and Güler, 2016). Every criterion has a range limit within which it is considered appropriate.

Georeferencing was done usingEarth Resources Data Analysis System(ERDAS) software using the projection system: UTM, Standard System Model: WGS 84. The sites for the observation, measurement or sample collection was done by generating a grid over the study area by using "create fishnet tool" in ArcGIS. Each square of the grid was of $1 \times 1 \mathrm{~km}$. All measurements, observations, and samples were taken as far as possible from the centroid of each grid. Sampling for the analysis of soil samples was done by taking three soil samples from each grid and mixing the three samples to form a composite sample which was taken as a representative sample of the grid. Soil sampling was done only for areas outside the municipal boundary. Soil samples were taken from a depth of $30 \mathrm{~cm}$. For ground water table a questionnaire survey of three pumps in each grid was done. The ownerof tube wells were questioned regarding the depth of the ground water. Wind direction was measured using a wind vane. Measurements were taken for 15 minutes at 8 a.m., 2 pm and 8 $\mathrm{pm}$ on each day of the month for one year. The height of measurements was $10 \mathrm{~m}$ above the ground. Wind observations were collected forNorth, North-East, East, East-South, South, South -West, West, and West-North directions. Wind speed was measured using anemometer (Luttron $\mathrm{AM}-4201)$. Measurements were made on the $\mathrm{kmh}^{-}$ ${ }^{1}$ scale. The measured values were grouped into 3 intervals $1-5 \mathrm{kmh}^{-1}, 5.1-15 \mathrm{kmh}^{-1}$ and $>15 \mathrm{kmh}^{-1}$. Less than $1 \mathrm{kmh}^{-1}$ was taken as calm. This data shows the frequency of wind direction and percentage of wind speeds in each direction. A wind rose was developed to know the average wind speed and direction of wind blowing over a one year period in the study area.

The population growth rate $(r)$ was calculated by given formula: $P_{2027}=P_{2011}(1+r)^{n}, n=$ number of years, $p=$ population. The overall growth rate for Rohtak city was $2.6 \%$. The per capita waste generation was $0.49 \mathrm{~kg} / \mathrm{day}$ as per data given by Rohtak Municipality (2012). For the estimation of area required for dumpsite the bulk density was calculated by following standard method given in "Municipal Solid Waste Management Manual", Ministry of Urban Development, 2014.

Models: To create suitability raster for the location of a waste disposal sites, the following model was created as shown in equation 1 , which is the sum of weight criteria multiplied by the product of restrictions. This site suitability model is made up of two models- Boolean Model (BM) and Index overlay model (IOM)(Eastman et al., 1995) which was generated in Geographical information system domain. Eleven criteria's were selected to accomplish the objective (Fig. 2).

$$
\mathrm{S}=\sum_{\mathrm{i}=1}^{\mathrm{n}} \mathrm{WiCi}_{\mathrm{i}=1}^{\mathrm{m}} \mathrm{Rj}
$$

$\mathrm{S}=$ Suitability for waste disposal site, $\mathrm{Wi}=$ Weight for criteria I (Ci), Ci= Criteria for suitability,

$\mathrm{Rj}=$ Restriction for suitability

Boolean model (BM): In Boolean Model(Kontos et al., 2005) the buffers have been created around roads, sensitive areas, canals, residential areas, railway tracks, drain, surface water bodies (Eq. 2). The output is a binary map because each location (pixel wise) is either satisfactory or not.

Formula

$\prod_{j=1}^{m} R j$

$\mathrm{Rj}=\mathrm{Rswb} \cdot \mathrm{Rr} \cdot$ Rcrd.Rra.Rsa.Rmcb

$\mathrm{Rswb}=$ Restriction related to surface water body $\mathrm{Rr}=$ Restriction related to roads

Rcrd $=$ Restriction related to canal, Railway line and Drain

Rra $=$ Restriction related to residential area

Rsa $=$ Restriction related to sensitive area

$\mathrm{Rmcb}=$ Restriction related to municipal corporation boundary

Layers: The evaluation factors taken for various types of buffering are as follows:

Roads: The buffer of 200 meters has been created on both sides of the roads(Fig.4 (A)). Buffering criteria of 200 meter ensure that when the model is run the dumpsite will be loaded at a mini distance of 200 meters from the roads. The mini distance from the road is essential to ensure that the vehicles transporting the waste do not accumulate on the road causing traffic problems and chances of mishaps. Dump waste attracts stray animals which may be a source of hazard to tragic if the dump is situated too close to road and railway track

Surface water: Buffering 200 meter has been created around surface water body (Fig.4 (B)). 200meter buffer around SWB prevents the leachate from leaching the sources of solid waste. Most water bodies will be situated in a depression hence is prone to leachate contamination due to runoff from the waste dumpsite during the rains (Matic et al., 2005; Sener et al., 2010; Paul S., 2012; Alavi et al., 2013; Hejal and Monereh, 2013; Pradhan and Samanta, 2015; Ahmad and Mahmood, 2015; Guler and Yomralloglu, 2017). Canal, Drain and railway track all were buffered of 100 meters. As all thses comes under line feature in GIS and have same buffering range of $100 \mathrm{~m}$ (Fig.4(C)) as prescribed under CPHEEO rules for landfill site selection, hence all these took in same layer.

Canal and Drain: Waste attracts the animals such as rats may damage canal embankment causing 


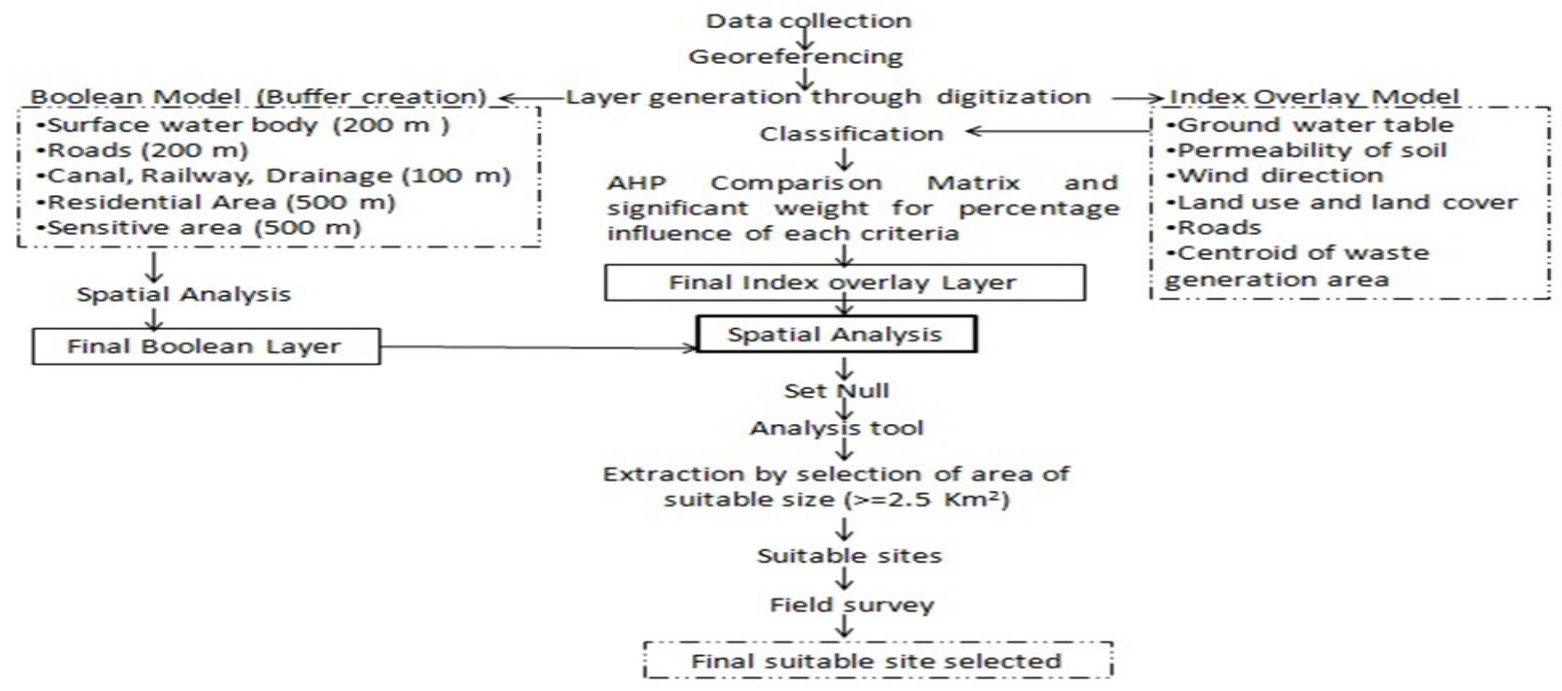

Fig.3. Flow chart of model applied for site suitability.

breach by burrowing (Alavi et al., 2013; Djokanovic et al., 2016). To ensure that contaminants do not reach the canal through run off or being blown by the wind, the buffering of 100 metersis created so, this buffering ensures that the dumpsite will be situated at a minimum distance of 100 meters from the canal when the model is run (Fig.4(C)).

Residential area: Buffer was generated to resist the pollution created by dumpsite such as air pollution, aesthetic value, odor pollution, noise, and pathogens. The establishment of landfills within cities, towns or villages is not suitable due to the unfavorable odor, waste spoilage, contamination by pathogens and noise; waste disposal areas must not be in the vicinity of the populated urban or rural areas, either (Alavi et al; 2013; Djokanovic et al., 2016). $500 \mathrm{~m}$ buffer was generated to residential area.

Sensitive area: Sensitive area sites layer was generated from theon-screen digitization of areas of archaeological and ecologically importance sites (Kontos et al., 2005; Zelenovic' et al., 2012; Yildrin et al., 2012; Alavi et al; 2013; Ahmet and Mahmood, 2015; Djokanovic et al., 2016). This research considered as sensitive area; Tilyar Lake and protected area of anarchaeological survey of India and are, therefore, $500 \mathrm{~m}$ was created around these sites (Fig.4 (E)).

Boolean raster data of the various criteria's was subjected to spatial analysis and raster calculation done for the evaluation of the final restriction layer which is shown in Fig.4 (F). The map is in a form of Boolean raster in which the pixel have been categorized into 2 i.e. 0 and 1.0 representing data pixels whose dumpsite cannot be located as per the applied criteria's and 1 representing these area pixel where these restriction criteria's do not apply meaning that the dump site can be situated in these areas.

Index overlay model (IOL): Index overlay model
(Eq. 3) was created by using the various criteria such as proximity to roads, proximity to residential areas, soil permeability, and proximity to built-up area. The final site selection of a suitable area was done by combining primary criteria were used - surface water body, roads, railway track, canal, drain, residential area, sensitive area, proximity from centroid of Municipal Corporation Limit (MCL), ground water table, soil permeability, wind Rose. Weightage to these primary criteria was allotted by using Analytical Hierarchy Process (AHP).The equation is given as following (Kontos et al., 2005; Cengiz and Akbulak, 2009; Poorna and Vinod, 2016)-

\section{$\sum_{\mathrm{i}=1}^{\mathrm{n}} \mathrm{WiC}_{\mathrm{i}}$}

WiCi $=$ Wgwt.Cgwt + Wps.Cps + Wwr.Cwr + Wlulc.Clulc + Wr.Cr + Wcmcb.Ccmcb

Wgwt and Cgwt = Weight and criteria for ground water table

Wps and Cps = weight and criteria for permeability of soil

Wwr and Cwr = weight and criteria for wind rose

Wlulc and Clulc $=$ weight and criteria for land use and land cover

$\mathrm{Wr}$ and $\mathrm{Cr}=$ weight and criteria for roads

$\mathrm{Wcmcb}$ and $\mathrm{Ccmcb}=$ weight and criteria for Cen-

Table 1. Pairwise Comparison Scale for AHP Preferences.

\begin{tabular}{ll}
\hline $\begin{array}{l}\text { Verbal Judgments of Pref- } \\
\text { erences }\end{array}$ & Numerical Rating \\
\hline Equally Preferred & 1 \\
Equally to Moderately & 2 \\
Moderately preferred & 3 \\
Moderately to Strongly & 4 \\
Strongly preferred & 5 \\
Strongly to very strongly & 6 \\
Very Strongly preferred & 7 \\
Very Strongly to Extremely & 8 \\
Extremely preferred & 9 \\
\hline
\end{tabular}


Deswal M. and Laura J.S. / J. Appl. \& Nat. Sci. 10 (2): 633 - 642 (2018)
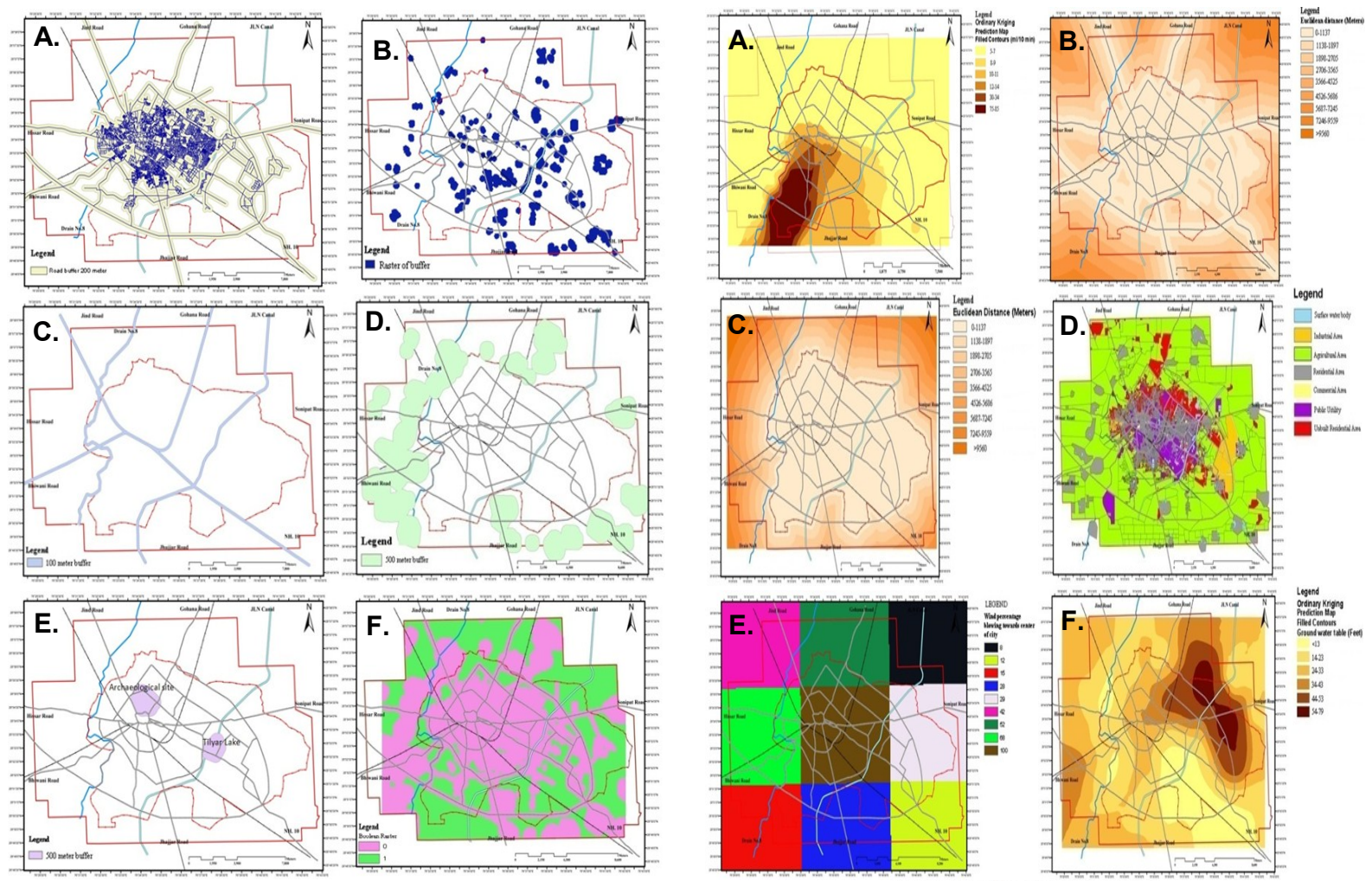

Fig. 4. Layers of Boolean Model- A- $200 \mathrm{~m}$ buffer around road network, $B-200 \mathrm{~m}$ buffer around surface water bodies, C- $100 \mathrm{~m}$ buffer around canal, railway line, drain, $D-500 \mathrm{~m}$ buffer around residential area, $E$ - $500 \mathrm{~m}$ buffer around sensitive area, F- Final restriction layer.

troid of municipal corporation boundary.

The summation of weightage criteria (Index overlay model) and product of Boolean modal was multiplied for the selection of final site, as given in equation 1. Final selection of the most suitable site was done by further evaluation of the size of the sites generated by the model and actual field visit to the site to determine the suitability on the basis of social acceptance. Working flow chart is shown in Fig. 3.

In AHP the factors to be analyzed are first of all arranged in an order of importance as determined by the analyst, this is a subjective step and may vary according to the expertise and experience of the analyst. In the next step, each factor is compared with all other factors in a pair-wise manner

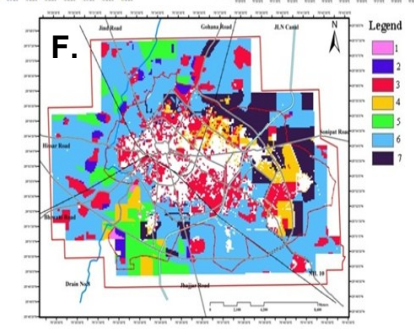

Fig. 5. Index overlay model- A- Kriging of ground water depth, B- Euclidean distance from roads, CEuclidean distance from waste generation center, $D$ Land use land cover, E-Wind direction, F- Kriging of permeability of soil, G- Final index overlay layer.

in terms of their relative importance. A pair-wise comparison matrix of the factors is made in a tabulated form in which $a_{i r}=1$ and $a_{i r}=1 / a_{i}$. the weight coefficient of the ranking criteria and the decision sub-criteria are calculated using the right eigenvector, which is calculated from maximum absolute eigenvector $\left(\lambda_{\max }, 1,2\right)$. The grading values of all the criteria are normalized to 1 .

Table.2. Comparison matrix of the criteria along with Eigenvectors of weights.

\begin{tabular}{lllllllll}
\hline Criteria & Wind & $\begin{array}{l}\text { Distance } \\
\text { from MC } \\
\text { limit }\end{array}$ & Road & $\begin{array}{l}\text { Soil per- } \\
\text { meability }\end{array}$ & $\begin{array}{l}\text { Ground } \\
\text { water table }\end{array}$ & $\begin{array}{l}\text { LUL } \\
\text { C }\end{array}$ & $\begin{array}{l}\text { Eigen } \\
\text { vector }\end{array}$ & $\begin{array}{l}\text { Weight } \\
\text { s \% }\end{array}$ \\
\hline Wind & $\mathbf{1}$ & 0.5 & 0.33 & 0.25 & 0.25 & 0.2 & 0.0464 & 5 \\
Distance from MC limit & 2 & $\mathbf{1}$ & 0.5 & 0.33 & 0.25 & 0.2 & 0.06544 & 7 \\
Road & 3 & 2 & $\mathbf{1}$ & 0.5 & 0.5 & 0.25 & 0.11013 & 11 \\
Soil permeability & 4 & 3 & 2 & $\mathbf{1}$ & 1 & 0.33 & 0.1829 & 18 \\
Ground water table & 4 & 4 & 2 & 1 & $\mathbf{1}$ & 0.33 & 0.1921 & 19 \\
LULC & 5 & 5 & 4 & 3 & 3 & $\mathbf{1}$ & 0.4029 & 40 \\
\hline \hline
\end{tabular}


Table. 3. Scheme of weight given to primary criteria and sub criteria's used in suitability model.

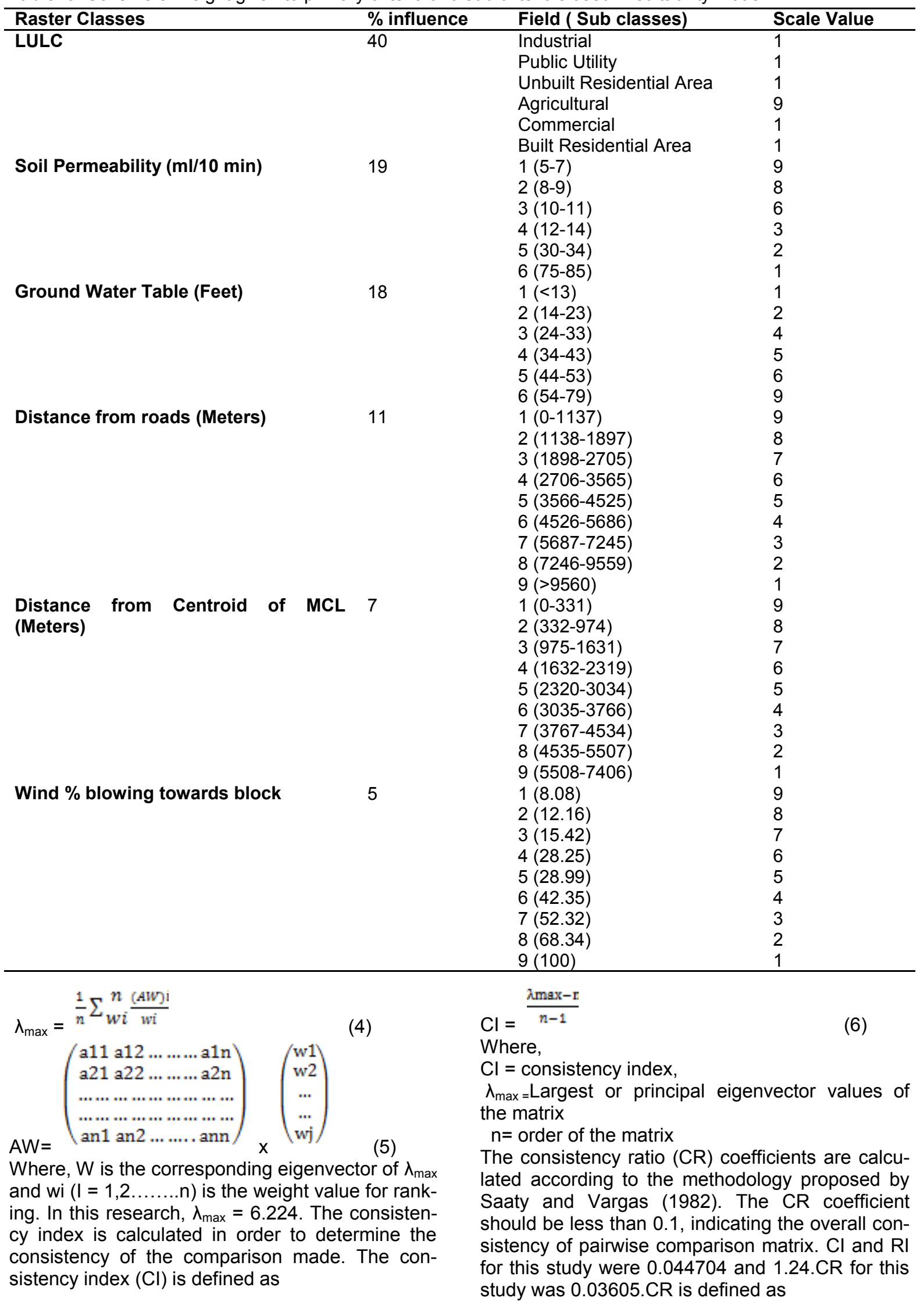




\section{$\mathrm{CR}=\frac{\mathrm{CI}}{\mathrm{RII}}$}

Where, RI is the average of the resulting consistency index depending on the matrix.

The use of AHP method using pair-wise comparisons in this present work is a suitable technique according to the relevant landfill site selection literature (Barakat et al 2017; Motlagh and Sayadi, 2015; Khan and Samadder, 2015; Chang et al. 2008., Gemitzi et al. 2007., Lin and Kao, 1998; Sumathi et al 2008; Yahaya et al., 2010; Chakbuk et al., 2016). However, there could be a different judgment for the relative magnitude of the criteria in comparison with pairs. The decision-making process in multiple criteria problems is a subjective process which depends on the decision makers. In a complicated problem such as landfill site selection, it seems logical for the people concerned to have different opinions (Kontos et al, 2005). In AHP, all criteria and factors are doubled up and are compared; the results are registered in a weighting index matrix there are nine scales ranging from 1 to 9 which gradually show priority factors (Saaty and Vargas 1982) such that 1 shows equal values, whereas 9 shows the maximum priority (Table 1 ).

Pairwise comparison matrix for the six factors/ criteria's used in the index overlay model is given in Table 2.

The weightages decided for the six criteria's or factors in percentage and for the subclasses of each criterion is presented in Table3. These quantitative values of weight age were decided from the AHP analysis described in the earlier section.

\section{Layers}

Ground water table: The depth of the water table is an extremely important factor (Barakat et al, 2017). Leachate percolation from dumpsite causes ground water contamination. The amount of soil burden on the aquifer act as an adsorption and filtration column for the leachate which may tend to percolates towards the water table. Hence the landfill location with lowest ground water level is more suitable for a landfill. This criterion is also important as aquifers are not static but dynamic and aquifer flow may cause contamination in areas distance from the landfill sites (Simsek et al., 2006; Paul, S., 2012; Hejal and Monereti, 2013;

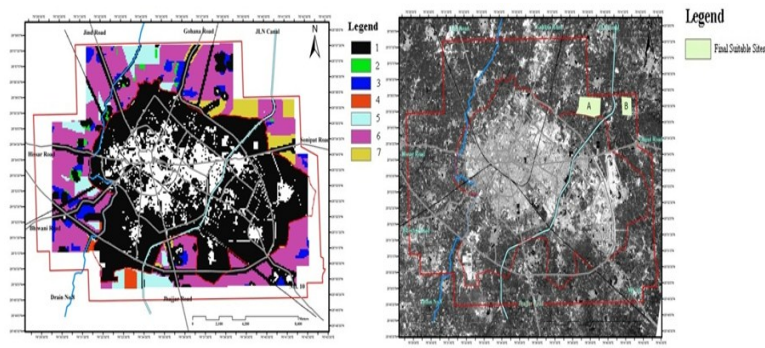

Fig. 6A). Classified image from 1-7. B) Final suitable dumpsites over Cartosat 1 imagery.
Paul et al., 2014; Pradhan and samanta, 2015; Samiullah et al., 2016; Nascimento et al., 2017). For interpolation kriging was applied. This criterion categorized the whole area in 6 zones (Fig.5 (F)). Among which range of 54-79 feet considered as a most suitable which has rating of 6 after reclassification and has scale value of 9 (Table.3). Higher the ground water level, it was least considerable. Permeability of the strata above the aquifers determines the percolation properties (Guler et al, 2017).

Soil permeability: Properties of the strata such as depth of overburden and type of soil determine the permeability of the strata to leachate released from the landfill. Properties of the strata such as depth of overburden and type of soil determine the permeability of the strata to leachate released from the landfill. The impermeability of the strata minimizes the risk of ground water pollution. The permeability of the strata is determined by the type of soil constituting the strata (Kontos et al., 2003; Simsek et al., 2006; Paul et al., 2014). In study area different composition of Clay and sandy soil were found which were classified into 6 classes (Fig.5 (A)). Least permeable (5-7 $\mathrm{ml} / 10$ minutes) was taken as a most suitable. After reclassification the rating of 9 was given to the same value (Table. 3).

Distance from roads: Landfill location must be close to road network for ease of transportation and consequently to reduce the cost. Landfill sites must be located near to an existing road as sitting of a landfill site in an area not serviced by the existing road network will incur an additional cost for the construction of a new road linking the landfill with the existing network. Hence landfill location must be close to road network for ease of transportation and consequently to reduce the cost (Sener et al., 2004; Guiqinet et al., 2009; Sener et al., 2011; Hejal and Monereh, 2013; Pradhan and Samanta, 2015; Rahmat et al., 2016; Samiullah et al., 2016; Guler, 2017). For same layer Euclidean distance were generated in GIS domain among which lowest distance from road was considered as a most suitable, hence reclassified 1 (0-1137 $\mathrm{m}$ ) field in distance from roads was given as highest scale value 9 which is given in Table 3, (Fig. 5 (B)). This criterion is implemented both in the restriction model as well as the index overlay model. In the restriction model a buffer of $200 \mathrm{~m}$ was created around the roads, this ensures that the waste site is at least some minimum distance from the road.

Distance from centroid of MCL: Taking into consideration the economic aspect of the waste transportation it is desirable that the landfill is located at a minimum distance from the waste generation center. However on the other hand if the environment and human aspect are taken into consideration the landfill should be far away from the resi- 
dential area (Chabuk et al, 2016; Baban and Flannagan, 1998; Rahmat et al., 2016).Landfill sites located close to the residential area cause health and environmental problems. Hence the Euclidian buffers from the municipal limit of 2010 are constructed to ensure this. Distance range of $0-331 \mathrm{~m}$ (Fig.5 (C)) was graded as highest rating of 9 .

Land use: The land use criteria differ from the land cover criterion as it aims to protect the sensitive area with economic development which may be affected due to the landfill pollution, air pollution ( due to odor) and opposition from the social point of view (Paul S., 2012; Paul et al., 2014; Pradhan and Samanta, 2015; Ahmad and Mahmood, 2015; Samiullah et al., 2016). The land use of study area was classified into seven categories: Industrial area, Agricultural area, commercial area, public utility, surface water bodies, residential area, and unbuilt residential area (proposed for residential but not constructed at present). As there was no unused and orchards were present in study area, therefore agricultural land was given rating of 9 , whereas other categories were assigned a score of 1 (Fig. 5(D)).

Wind direction: There is no legal restriction or recommendation for wind direction. The wind direction frequency was considered as criteria for the site selection (Kontos and Halvadakis, 2002; Djokanovic et al., 2016). The direction of prevailing winds is a factor which influences the quality of the air in the downstream direction. Due to biological and chemical decomposition of waste at dumpsites, show emission of various gasses. The emission of gasses is likely to be high. It is the major contributor of gasses. The various gasses emitted can be but in the general categories of following classes of compound-Bad quality of air causes discomfort to the residential inhabitants. Hence while selecting the site of dump wind direction is one factor which is taken into account. The directional frequency of wind can be taken from the wind rose data. Study area was classified into nine classes for the wind percentage blowing towards the blocks (Fig. 5(E)). Among these rating of $9,8,7$ were given to $8.08 \%, 12.16 \%, 15.42 \%$, whereas I rating given to $100 \%$.

Final map of Index overlay model was generated after merging of all layers (Ground water table, roads, waste generation center, Land use land cover, Wind direction, permeability of strata) (Fig. $5(G)$ ). The final map is classified into seven categories on the basis of suitability. As the numerical values of pixel increases the suitability of that pixel for dumpsite increases. Therefore, pixel value of seven was considered as the most suitable for the dumpsite.

\section{RESULTS AND DISCUSSION}

As a result from restriction model and suitability model, two images were generated. The result of restriction model was generated on basis of buffering of various features and map containing only two classes- 0 (non-suitable) and 1 (Suitable) (Fig.4.(F)). In suitability model, the result was generated on the basis of weightage given to each criteria based on its importance. The study area has been classified into 7 categories from 1 to 7 . The increasing number represents the increasing suitability. Area falling in category 1 is least suitable whereas area falling in category 7 is most suitable Fig.5 (G). The combination of the tworesulting maps of Boolean and IOL models in the spatial analysis tool yield the map given in figure 6(A), in which the class- 0 areas are excluded. Map in Fig.6 (A) also has seven classes. Six sites fall within the most suitable category(Class7). Further selection from these six most suitable sites is done on the basis of size suitability of the sites. The size of the site should be able to handle waste for next 10 years.

The estimated population in Rohtak city in 2027 is 691210 inhabitants, calculated according to the population growth rate. The cumulativeten year solid waste generation will be 1200120 tons. The calculated value of waste density of Rohtak city is $450 \mathrm{~kg} / \mathrm{m}^{3}$. Consequently, the volume of waste is $2666933 \mathrm{~m}^{3}$. Taking the deepness of the water table into consideration, the average height for waste was adopted as 2 meter from below the surface. Accordingly the area required to accommodate the quantity of solid waste generatedup to 2027 was found to be $1.333 \mathrm{~km}^{2}$. Observing the attributional data of class 7 of fig. 6(A), two sites meet the minimum size requirement for establishing the landfill site A and Site B (Fig. 6(B)). A field survey of the final two sites was carried out and on the basis of the survey the site $B$ was selected to be the most suitable. The area of site $B$ is 3.75 $\mathrm{km}^{2}$ (Latitude $28^{0} 55.492^{\prime} \mathrm{N}$ and longitude $\left.76^{\circ} 41.339^{\prime} \mathrm{E}\right)$. Site $A$ is less suitable as it is surrounded by a cluster of villages. Although site $A$ is more than $500 \mathrm{~m}$ from the surrounding villages at present, the expansion of the villages may result in the violation of the criteria at a later stage. Wind blowing over the site $A$ will flow over downwind village MakdolliTehlan. The site $A$ has high tension wires going over it, which may pose fire hazard. Interaction with villagers regarding their choice from the two locations for setting up of the MSW disposal site, the acceptability for site B was more.

\section{Conclusion}

Selecting the site of a landfill adhering to recommendations and regulations of regulatory bodies is a technically challenging issue, but economically beneficial, as it ensures a first time proper selection avoiding environmental problems and shifting of the site at a later stage. The study has ensured that all factors and regulations were used with a 
combination of techniques such as GIS and AHP. The criteria chosen for the models adhere to the rules and regulations notified by CPHEEO and $\mathrm{CPCB}$. The use of AHP revealed the relative importance of the selected criteria and assisted in assigning the weightage for each criterion. The criteria were used in Boolean and Index overlay models to arrive at the most suitable sites for the development of a landfill for disposal of the MSW of Rohtak city. The modeling studies shortlisted six sites as being the most suitable. Further selection was done on the basis of size requirement to handle the city waste up to 2027 . Out of the six sites, only two sites fulfilled the size requirement. Out of which site B was selected on the basis of field survey which revealed it being better on account of certain factors and social acceptability.

\section{REFERENCES}

Ahmad, S.R., and Mahmood, K.(2015). GIS based landfill site selection for Faisalbad city. International Journal of Scientific \& Engineerign Research, 6(4):67-72

Alavi, N., Goudarzi, G., Babaei, A.A., Jaafarzadeh, H.N., Hosseinzadeh, M (2013). Municipal solid waste landfill site selection with geographic information systems and analytical hierarchy process: a case study in Mahshahr County, Iran. Waste Management and Research, 31(1):98-105.

Alanbari, M.A., Al-Ansari, N., and Jasmin, H.K (2014). GIS and multicriteria decision analysis for Landfill site selection in Al-Hashemiyah Qadaa. Natural Science, Vol.6, pp. 282-304, http://dx.doi.org/10.4236/ ns.2014.65532.

Baba, M.E., Kayastha, P., Smedt, F.D., (2015). Landfill site selection using multi-criteria evaluation in the GIS interface: a case study from the Gaza Strip, Palestine. Arabian Journal of Geosciences, 8, 7499-7513.

Baban, S. M. J. and Flannagan, J., (1998). "Developing and implementing GIS-assisted constraints criteria for planning landfill sites in the UK." Planning Practice and Research, 13(2.): 39-151, DOI: 10.1080/ 02697459816157.

Barakat, A., Hilal, A., Baghdadi, M.E., Tauhami, F., (2017). Landfill site selection with GIS-based multicriteria evaluation technique. A case study in Beni Mellal-Khouridga region, Morocco, Environmental Earth Sciences, 76:413.

Cengiz, T., Akbulak, C., (2009). Application of analytical hierarchy process and geographic information systems in land-use suitability evaluation: a case study of Dumrek village (Canakkale, Turkey), International Journal of Sustainable Development \& World Ecology,16(4);286-294.http: dx.doi.org /10. $1081 / 1350$ 4500903106634

Central Pollution COntrol Board (CPCB), New Delhi, (1999). Deveopment of site selection methodology for land filling- A case study for Bangalore, Hazardous Waste Management Series, HAZWAMS/22/200203,12 .

Chakbuk, A., Al-Ansari, N., Hussain, H.M., (2016). Landfill site selection using geographic information system and analytical hierarchy process: A case study Al-Hillah Qadha, Babylon, Iraq. Waste Management \& Research., 34, 5:427-437. https:// doi.org/10.117/0734242x16633778.
Chang, N, Parvathinathanb, G, Breden, J.B., 2008. Combining GIS with fuzzy multicriteria decision making for landfill siting in a fast-growing urban region. Journal of Environmental Management 87: 139153.

Dipanjan, S., Vinod, T., Onkar, D., 1997. Ranking potential solid waste sites using geographic information system techniques and AHP, National Seminar on Applications of GIS for Solving Environmental Problems Chennai, 98-106.

Djokanovic, S., Abolmasov, B., Jevremovic, D., 2016. GIS application for landfill site selection: a case study in Pancevo Serbia. Bull Eng. Geol. Environ., 75:12731299.

Eastman, J.R., Jin, W., Kyem, P.A.K., Toledano, J., 1995. Procedures for multi-criteria/multiobjective decisions. Photogrammetric Engineering and Remote Sensing, 61:539-547.

Gemitzi, A., Petalas, C., Tsihrintzis, V.A., Pisinaras, V., (2007). Assessment of groundwater vulnerability to pollution: a combination of GIS, fuzzy logic and decision making techniques. Environmental Geology 49 (5), 653-673.

Guler, D., Yomralioglu, T., (2017). Alternative suitable landfill site selection using analytic hierarchy process and geographic information systems: a case study in Istanbul. Environmental Earth Sciences, 676-678.

Guiqin W, Li Q, Guoxue L, Lijun C., 2009. Landfill site selection using spatial information technologies and AHP: a case study in Beijing, China. J Environ Eng 90:2414-2421.

Hejal, D.A., and Monereh, M., (2013). GIS and the analytic hierarchy process methods for site selection of waste landfills: a case study in Iran. International Journal of Geology, Earth and Environmental Sciences, 3(3):96-104.

Kontos, T.D., Komilis, D.P., Halvadakis, C.P., (2005). Siting MSW landfill with a spatial multiple criteria analysis methodology. Waste Management, 25:818-832.

Kontos T, Komilis D, Halvadakis C., 2003. Siting MSW landfills on Lesvos island with a GIS based methodology. Waste Manag Res,21:262-277.

Khan, D., Samadder, S.R., 2015. A simplified multicriteria evaluation model for landfill site ranking and selection based on AHP and GIS, J. Environ. Eng. Landsc. Manage., 23(4):267-278.

Lin, H. and Kao, J., 1998. Enhanced Spatial Model for Landfill Siting Analysis. Environmental Engineering, 125 (9): 845-851.

Matic' I, Martinovic' M, Vujasinovic' S., 2005.Determination of sanitary protection of groundwater sources Panc evo. The $14^{\text {th }}$ Congress of Geologists of Serbia and Montenegro.

Malczewski, J., 2004. GIS- based land-use suitability analysis: a critical overview. Progress in Planning, 62 (1):3-65.

Ministry of Environment, Forests and Climate Change (MoEFCC), 2016. Solid waste management rules revised after 16 years; rules now extend to urban and industrial areas: Javedkar. Central Monitoring Committee Under Environment Secretary to Monitor Implementation, press Information Bureau, Government of India (Gol).

Ministry of Urban Development, 2014. Municipal solid waste management manual, Central Public Health and Environmental Engineering Organisation (CPHEEO), Government of India. 
Motlagh, Z.K., Sayadi, M.H., (2015). Siting MSW landfills using MCE methodology in GIS environment (Case study: Birjand plain, Iran), Waste Manag., 46:322-337.

Nascimento, V.F., Yesiller, N., Clarke, K.C., Ometto, J.P.H.B., Andrade, P.R., Sobral, A.C., 2017. Modeling the environmental susceptibility of landfill sites in California. GIScience \& Remote Sensing, 1-21.

Nascimento, V.F.,Sobral, A.C., Andrade, P.R., Ometto, J.P.H.B., Yesiller, N., (2017). Modeling Environmental Susceptibility of Municipal Solid Waste Disposal Sites: A case study in Sao Paulo State, Brazil. Journal of Geographic Information System, 9:8-33.

Paul, K., Dutta A., Krishna, A.P., 2014.A comprehensive study on landfill site selection for Kolkata City, India. Journal of the Air and Waste Management Association, 64(7):846-861.

Paul, S., (2012). Location allocation for urban easte disposal site using multi-criteria analysis: A study on Nabadwip Municipality, West Bengal, India. International Journal of Geomatics and Geosciences, 3(1):74 $-88$.

Poorna, A.C., Vinod, P.G., (2016). Solid waste disposal site selection by data analysis using GIS and Remote Sensing tools: A case study in Thiruvananthapuram Corporation area. International Journal of Geomatics and Geosciences, 6(4):1734-1747.

Pradhan, J and Samantha, K., (2015). Site suitability analysis using remote sensing and GIS for proper selection of solid waste disposal gound within Rajarhat Gopalpur Municipal area, Kolkata, West Bengal. International Journal of Scientific \& Engineering Research, 6(4):67-72.

Rahmat, Z.G., Niri, M.V., Alavi, N., Goudary, G., Babaei, A.A., Baboli, Z., Hosseinzadah, M., (2017). Landfill site selection using GIS and AHP: a case study: Behbahan, Iran. KSCE Journal of Civil Engineering, 21(1):111-118. DOI 10.1007/s12205-016-0296-9.

Sadek, S., El-Fadel, M., Freiha, F., (2006). Compliance factors within a GIS-based framework for landfill siting. International Journal of Environmental Studies, 63, 71- 86

Samiullah, Rahman, A., Shah, S.A.A., Khan, Z., Nawaz, S., (2016). Identification of suitable sites for Solid Waste Disposal using GIS, Multi-criteria Analysis in Peshawar, Pakistan. Proceedings of the Pakistan Academy of Sciences, B.Life and Environmental Sciences, 53(4):309-321.

Swachh Bharat Mission, (2016). Municipal solid waste management manual, Central Public Health and Environmental Engineering Organisation (CPHEEO), Ministry of urban development, Government of India.

Saaty, T.L., Vargas, L.G., (1982). The Logic of Priorities; Applications in Business, Energy, Health, and
Transportation, Boston: Kluwer-Nijhoff. Reprinted in Paperback (1991), Pittsburgh: RWS Publications.

Shahabi, H., Keihanfard, S., Ahmad, B.B., Amiri, M.J.T., (2014). Evaluating Boolean, AHP and WLC methods for the selection of waste landfill sites using GIS and satellite images. Environmental Earth Sciences, 71, 4221-4233.

Sener S, Sener E, Karaguzel R., (2011). Solid waste disposal site selection with GIS and AHP methodology: a case study in Senirkent-Uluborlu (Isparta) Basin, Turkey. Environ Monit Assess 173:533-554.

Şener, Ş., Şener, E., Nas, B., Karagüzel, R., (2010). Combining AHP with GIS for landfill site selection: A case study in the Lake Beyşehir catchment area (Konya, Turkey). Waste Management, 30, 2037-2046.

Simsek C, Kincal C, Gunduz O (2006) A solid waste disposal site selection procedure based on groundwater vulnerability mapping. Environ Geol 49:620-633.

Solid Waste Management Rules, 2016. Ministry of Environment, Forestry and Climate change, Government of India.

Swachh Bharat Mission, 2016. Municipal solid waste management manual. CPHEEO, Ministry od Urban Development (MoUD)

Sumathi, V.R., Natesan, U., Chinmoy, S., 2008. GISbased approach for optimized siting of municipal solid waste landfill. Waste Management, 28, 2146-2160.

Vasiljevic, T.Z., Srdjevic, Z., Bajcetic, R., Miloradov, M.V., 2012. GIS and the Analytic Hierarchy Process for Regional Landfill Site Selection in Transitional Countries: A Case Study From Serbia. Environmental Management, 49, 445-458.

Yal, G.P., Akgün, H., 2013. Landfill site selection utilizing TOPSIS methodology and clay liner geotechnical characterization: a case study for Ankara, Turkey. Bulletin of Engineering Geology and the Environment, 73, 369-388.

Yahaya S, Ilori C, Whanda S, Edicha, J., 2010. Landfill site selection for municipal solid waste management using geographic information system and multicriteria evaluation. Am J Sci Res 10: 34-49.

Yıldırım, V., 2012. Application of raster-based GIS techniques in the siting of landfills in Trabzon Province, Turkey: a case study. Waste Management \& Research, 30, 949-960.

Yıldırım, Ü., Güler, C., 2016. Identification of suitable future municipal solid waste disposal sites for the Metropolitan Mersin (SE Turkey) using AHP and GIS techniques. Environmental Earth Sciences, 75, 101.

Zelenovic' Vasiljevic' T, Srdjevic' Z, Bajčetic' R, Vojinovic M., 2012. GIS and the analytic hierarchy process for regional landfill site selection in transitional countries: a case study from Serbia. Environ Manage 49:445-458. 